\title{
A Magyar Szent Korona Országai Vörös-Kereszt Egylete Somogy vármegyei fiókegyletei és tevékenységük az I. világháború idején
}

\author{
GÁSPÁR FERENC
}

7400 Kaposvár, Kossuth Lajos utca 10., e-mail: drgasparferenc@t-online.hu

\begin{abstract}
GÁspár, F.: The Branches of the Red Cross Association of the Countries of the Hungarian Holy Crown in Somogy and their Activities during the First World War.

Abstract: The Red Cross Association of the Countries of the Hungarian Holy Crown was founded on 16th May 1881 in Budapest, with the aim of carrying out humanitarian activities in addition to the curing and caring of injured or sick war veterans, going beyond military attendance and complementing state attendance. Between 1887 and 1899 ten branches were founded in Somogy. In addition to the already existing branches of the county seat, the patriotic fervor following the breakout of the war resulted in the establishment of 53 further healthcare facilities with altogether 1822 beds for the injured soldiers in 40 municipalities. This is the very first essay to describe their activities, disclosing detailed monitoring data about the amount of donations. The essay describes in detail the history of the two largest branches of the county (Balatonlelle and Szigetvár).
\end{abstract}

Keywords: World War I, Somogy county, Red Cross, wounded soldiers, hinterland support

Az 1881. május 16-án Budapesten megalakult Magyar Szent Korona Országai Vörös-Kereszt Egylete ${ }^{1}$ a háborúban megsebesült vagy megbetegedett katonák gyógyításában, ápolásában a katonai gondozás mértékén túlmenő, az állami gondoskodást kiegészítő humanitárius tevékenység megvalósítására jött létre. A megalakulását követő napon csatlakozott hozzá az 1879 óta Erzsébet királyné védnökségével müködő Magyar Országos Segélyező Nőegylet. ${ }^{2}$ Országos hatókörü egyletként egyik legfontosabb feladatának tekintette a vidéki fiókhálózat létrehozását. Somogy megyében ez az igyekezet évekig nem járt sikerrel, csak 1887-ben alakult meg elsőként a kaposvári fiókegylet. ${ }^{3}$

1 A sajtóban az egylet nevének írásmódja kaotikus, olykor még azonos mondaton belül is változó (Vörös-Kereszt, Vörös-kereszt, vörös-kereszt, Vöröskereszt, vöröskereszt stb.). Hivatkozásoknál, idézetekben megtartottam az eredeti forrásokban található alakot. A hivatalos név az idők során változott is: alakulásától Magyar Szent Korona Országai Vörös-Kereszt Egylete, 1918-tól Magyar Vörös-Kereszt, napjainkban Magyar Vöröskereszt. Hasonló bizonytalanság észlelhető a fiókegyletek megnevezése körében is, hol egyletnek, hol egyesületnek nevezik öket.

2 Amikor az Osztrák-Magyar Monarchia csapatai 1878-ban megindították Bosznia-Hercegovina okkupációját, számos jótékony célú, gyűjtést folytató nőegylet elhatározta, hogy egyesülnek, ezzel nagyobb hatásfokkal, országosan szervezett keretek között segélyezhetik a katonákat és otthon maradt rászoruló családtagjaikat. Így jött létre 1879-ben a Magyar Országos Segélyező Nőegylet.

3 A somogyi és a kaposvári datálásokkal kapcsolatosan sok a bizonytalanság. Bősze Sándor tanulmányában (Bősze 1986: 303. 314.) írja: „az alispáni nyilvántartások pontatlanok, hiányosak, különösen igaz ez a vöröskereszt fiókegyesületek vonatkozásában”. A kaposvári fiókegylet megalakulásának idejét a Magyar Szent Korona Országai Vörös-Kereszt Egyletének 1902. évi jelentése alapján határoztam meg (Jelentés 1902: 16). Tevékenységét külön tanulmány ismerteti: Gáspár 2018.
Egy éven belül sikerült létrehozni további öt helyen, így már működhetett az összefogásukra hivatott megyei választmány, amely 1888-ban kezdte meg munkáját. Elnöke Tallián Béla föispán, alelnöke Németh Ignác polgármester lett.

A Vörös Kereszt Egyletre jellemzö, hogy mindenütt nagy tekintélyű vagy hivataluknál fogva jelentős befolyásolási képességgel rendelkező vezetőket választottak első számú tisztségviselőknek. Amikor a főispán távozott a megyéből, utóda az egylet élén a jótékonykodása révén közismert őrgrófné, Pallavicini Edéné lett. ${ }^{4}$ Évente hosszabb időt töltött mosdósi otthonától (és a megyétől) távol, ezért 1900 elején lemondott tisztségéröl. Csak miután ismételten bebizonyosodott, hogy elhatározása végleges, fogadta el az új főispán, Tallián Gyula az országos központ ösztönzésére a felkérést: „legyen szabad újólag kérnünk, hogy a Somogy-megyei vörös-kereszt választmány végleges megalakítása, illetőleg a tiszti állások betöltése iránt intézkedni, az elnöki állásnak magára vállalása által a magasztos eszme iránti érdeklődésnek új irányt adni, az ügymenet rendszerességét szokott erélyével biztosítani, $s$ minket az elért eredményröl értesíteni szíveskedjék". ${ }^{5}$ Az új megyei választmány 1901. október 17-én alakult meg, akkor már tíz fiókegylet ${ }^{6}$ volt a vármegyében. Elnöke Tallián Gyula főispán, társelnöke dr. Goszthony Mihályné, alelnöke Maár Gyula alispán, társalelnöke Svastics Aladárné, pénztárnoka Sárközy Béla, jegyzője Psik Andor lett ${ }^{7}$ (1. táblázat ${ }^{8}$ ).

1890-ben már 417 olyan fiókegylet van a Szent Korona országaiban, amely valamely választmányhoz tartozik, további 245 önállóan müködik. Ismertségük, társadalmi tekintélyük olyannyira megnőtt, hogy a Vöröskereszt neve és jelvénye a kereskedelemben, de magánszemélyek esetében is „áruvédjeggyé” kezdett válni. A visszaélések megakadályozására jelent meg az 1286/1889. július 6. sz. B. M.-körrendelet, amely kimondta, hogy a Vöröskereszt nevének és jelvényének „mindennemü használati igényét” be kell jelenteni

4 Pallavicini Edéné Majláth Etelka (1853-1936), a „szegények segítője", 1890-től a Budai Jótékony Nőegylet elnöke.

5 MNL SML X. 202. A vöröskeresztegylet 3557. számú levele a föispánhoz, 1900. augusztus 18.

6 A 3. lj. alatt hivatkozott jelentés adatai alapján.

7 MNL SML X. 202. 25/1901. október 23.

8 Jelentés 1902 (A Magyar Szent Korona Országai Vörös-Kereszt Egyletének 1902. évi jelentése): 10. A tagsági viszony kategóriáit az alapszabály szerint a belépéskor fizetett összeg határozta meg. Ennek értelmében az egyszer és mindenkorra fizetett 40 korona alapító, 20 korona örökös, illetve hat éven át évi 2 korona rendes, 1 korona rendkívüli tagságot eredményezett. A későbbiekben a tagsági „minőség” említése változatos, például hol „40 koronás”, hol „örökös” tagként kerül nyilvántartásba. 
1. táblázat. A Somogy vármegyei fiókegyletek az 1902. évi állapot szerint

\begin{tabular}{|c|c|c|c|c|c|c|c|}
\hline & Fiókegylet & Alapítási év & $\begin{array}{c}\text { Alapító tag } \\
(40 \text { korona })\end{array}$ & $\begin{array}{c}\text { Örökös tag } \\
(20 \text { korona })\end{array}$ & $\begin{array}{c}\text { Rendes tag } \\
(2 \text { korona })\end{array}$ & $\begin{array}{c}\text { Rendkívüli tag } \\
(1 \text { korona })\end{array}$ & Összesen \\
\hline 1. & Kaposvár & 1887 & 35 & 52 & 178 & - & 265 \\
\hline 2. & Lengyeltóti & 1887 & 3 & 6 & 102 & - & 111 \\
\hline 3. & Nagyatád & 1887 & 5 & 17 & 167 & - & 189 \\
\hline 4. & Marcali & 1888 & 4 & 12 & 69 & 1 & 86 \\
\hline 5. & Tab & 1888 & 1 & 4 & 28 & - & 33 \\
\hline 6. & Tarnóca és vidéke & 1888 & 3 & 17 & 61 & 4 & 85 \\
\hline 7. & Csurgó & 1890 & 2 & 4 & 49 & - & 55 \\
\hline 8. & Gyékényes & 1898 & - & - & 10 & - & 1 \\
\hline 9. & Szigetvár és vidéke & 1899 & 9 & 7 & 104 & 6 & 126 \\
\hline 10. & Balatonboglár & 1899 & 1 & 4 & 51 & - & 56 \\
\hline
\end{tabular}

a területileg illetékes választmányhoz. A választmány véleményével együtt (amelynek tartalmaznia kell, hogy az igény teljesülésével „nem szenved csorbát az az egylet méltósága”), fel kell terjeszteni azt az országos központhoz, ahol döntenek az elfogadásról vagy elutasításáról. A rendelet kimondta, hogy akik a megadott határidőig nem folyamodnak az engedélyért, „hatóságilag eltiltatnak" a jelvények további használatától.

Egy estleges háborúra való felkészülés katonai tervezése során a Hadügyminisztérium már 1885-től kezdődően számba vette azokat a helyeket, amelyek a katonai egészségügyi szolgálat számára feladata ellátásához szükségesek lehetnek. Ezek sorába Gyékényes is beletartozott. Ennek ellenére csak tizenhárom évvel később kérték fel a főispánt, hogy szervezze meg ott egy fiókegyesület létrehozását, mert tizenkét ágyas „betegüdítő” állomást kívánnak a vasútállomáson létrehozni, amelynek működtetése a vöröskereszt feladata lesz. ${ }^{9}$ A főszolgabíró válaszában fiókegylet létrehozását lehetségesnek tartja (tíz személynek kell belépni a megalapíthatósághoz), de a konyha, orvos, ápolónő hiánya miatt a betegüdítőt nem gondolja megvalósíthatónak. 1898 közepére a fiókegylet megalakul ugyan, ám a további ügyintézés nehézkesen halad. Erről tanúskodik a Vörös-Kereszt Egylet Központi Igazgatóságának három évvel később kelt sürgető levele: „Még 1898. évi október hó 4-én kérelmet intéztünk a gyékényesi vörös-kereszt fiókegylethez, hogy miután háború esetén Gyékényesen, a vasúti állomáson betegüditő állomást kell fenntartanunk, az elökészítő munkákat a fiókegylet vállalja magára, és erről szabályszerü beadványt állitson ki. A fiókegylet elnöke, Tóth Imre körjegyző úr kilátásba helyezte az ügy elintézését, azonban Gyékényesröl elköltözvén, az elnökségben őt követő Szabó Lajos körjegyző úr, dacára ismételt sürgetéseinknek, nem ad választ leveleinkre, és így nem is vagyunk tájékozva az iránt, hogy a betegüditő állomás előkészítése ügyében történt-e valami, és különösen az 1901. évi január hó 10-én 40. szám alatt kelt átiratunkban foglalt egyes részletek milyen elintézést nyertek. Miután igen kívánatos, hogy

$9 \quad$ MNL SML X. 202. 388/1898. február 7. ezen évek óta húzódó ügy véglegesen megoldassék, felkérjük méltóságodat, szíveskedjék odahatni, hogy a gyékényesi fiókegyesület és föleg Szabó Lajos elnök úr a kérdéssel sürgősen foglalkozzék, és a beadványokat oly értelemben állítsa ki, mint azt kérelmeztük. Megjegyezzük, hogy mi után tudomásunk szerint orvos nem áll rendelkezésre, egyidejüleg kértük a 4-ik hadtest parancsnokságát az orvosnak a mozgósítást követően 8-ik napon hivatalból való kirendelése iránt. Továbbá ápolókat és sebesültvivőket a honvédség állományából fogunk kérni."

A megyei választmánytól érkező felkérések számos helyen nem találnak fogadókészségre, felszólításokkal más esetekben is találkozhatunk: „Tallián Gyula föszolgabíró Úrnak. A szent Ferenc rendiek felsősegesdi rendháza a Somogyvármegyei Vörös Kereszt egyletbeli választmányának a sebesült és beteg harcosok háború esetén leendő felvétele iránt hozzá intézett felszólitást felbontatlanul visszaküldvén, felkérem tekintetes föszolgabíró urat, hogy a mellékelt felszólitást nevezett rendháznak kézbesíteni szíveskedjen." $" \mathrm{Ka}$ posváron sem más a helyzet: a város területéről nem érkeznek be válaszok, felajánlások.

Csurgó 1889. február 6-án kelt levelében vállalja 28 katona és 2 tiszt elhelyezését, az orvosi felügyeletet, de ápolót nem tud biztosítani. Ezzel szemben teljesíthetetlenül magas, napi 6 korona költségtérítést kérnek, ráadásul nem saját tulajdonú ingatlanban, hanem a működő iskolában történő elhelyezést ajánlják fel. A központ nem igazán elégedett a felajánlásokkal, kéri a föispánt, hasson oda, hogy nagyobb legyen azok száma. Tizenegy földbirtokostól 51 helyre van ígérvény, de közülük mindössze hárman fogadnának be 6-6 személyt, a többiek kevesebbet.

Nemcsak ezzel, hanem magával a müködéssel kapcsolatosan is találkozunk nehézségekkel, aminek egy esetét a nagyatádi fiókegylet jelentése nyomán mutathatjuk be. „A müködését még 1892-ben beszüntetett

10 MNL SML X. 202. 894/1901. február 28. A sürgető levélben hivatkozott 40. számú átiratra nem leltem rá.

11 MNL SML X. 202. 52/1888. Később a Szent Ferenc Rendház négy fö elhelyezését vállalja, minden egyéb kötelezettség (betegszállítás, ápolás, élelmezés stb.) nélkül. 
és feloszlatott nagyatádi fiókegylet újjászervezése iránt alapszabályszerü kötelességünkből kifolyólag több ízben tettünk kísérletet, mely végre különösen Széchényi Aladár gróf kiváló ügybuzgósága folytán eredményre vezetett, a fiókegylet múlt évi (1901, betoldás tőlem, G. F.) november 20-án a nagyatádi községházban tartott népes összejövetelen újjáalakulását kimondotta. Megválasztotta a választmányi tagokat, és szervezte a tisztikart, s már eddig is azon örvendetes tényről számolhat be, hogy 189, részben alapító, részben 20 koronás és 2 koronás évdíjas taggal rendelkezik. Vagyona a tőkésített kamatokkal 1294 korona 65 fillér."12

A Hadügyminisztérium jelölte ki azokat a katonai létesítményeket, ahol a Vöröskereszt tulajdonába átadott berendezési tárgyakat, felszerelést tárolták. Esetünkben - az egész megyére érvényesen - ez a 44-es gyalogezred kaposvári csapatkórháza. Tekintettel arra, hogy a háború esetére elkülönített egészségügyi felszerelések, kötszerek időnkénti felülvizsgálata fontos volt, mert a hosszú tárolás során a használhatóságukban károsodást szenvedhettek, időről időre elvégezték azt. Az öt személyből álló felülvizsgálati bizottság három tagja a vöröskereszt helyi választmányából, két tagja a hadsereg állományából került ki. „Megnyugvással” állapították meg, hogy a fehérneműk és az ápolási anyagok állapota jó, bármikor kiszállíthatók a lehetséges ellátóhelyekre. ${ }^{13}$

A háború kitörésének híre és a valamennyi lapban közzétett belügyminiszteri felhívás - amelyet a helyi elöljáróságok bevonásával széles körben nyomatékosítottak - egy csapásra megváltoztatta a korábbi évekre jellemző érdektelenséget, a társadalom lelkesedéssel és önként tett eleget a kérésnek: „Hadseregünk hadra kelt. Fiaink, testvéreink, drága véreink indulnak háborúba. [...] A hadi szervezet a rendelkezésére álló intézményekkel gondoskodik egészségük megóvásáról, harcképességük fenntartásáról. [...] Ezt a nemes célt szolgálja a vörös kereszt intézménye. [...] Felhívom az alispán urat, hogy a vörös kereszt egyesület eszközeinek gyarapítására, emberséges tevékenysége támogatására most, végzetes események küszöbén a helyi társadalom körében haladéktalanul mozgalmat indítson, és tevékenysége eredményét jelentse be. [...] Felhívom tehát alispán urat, hogy ahol nincs még a vörös keresztnek választmánya, illetve fiókja, ilyennek felállítására törekedjék, és egyben hívja fel e helyi társadalmat, hogy a harctéri sebesültek és betegek sorsának könnyítéséhez, egészségük helyreállitásához járuljon hozzá ki-ki, amivel teheti, pénzzel vagy természetben szolgáltatandó adományokkal, helyiségek kórházi célra való átengedésével, ápolói vagy egyéb személyes szolgálatra való ajánlkozással."14

12 MNL SML X. 202. 965/1902. március 2

13 MNL SML X. 202. 772/1903. március 17. A bizottság tagjai: Sárközy Béla föszolgabíró, dr. Szigethy-Gyula Sándor kórházigazgató főorvos, Psik Sándor főispáni titkár, dr. Száhlender Ferenc ezredorvos, a katonai kórház parancsnoka és Scheidl Károly föhadnagy.

14 Somogy a sebesült katonákért. Somogyvármegye, 1914. augusztus 7. 4 .
A fiókegyletek és a magánszemélyek egymással versengve tették meg felajánlásaikat, a gyüjtések, gyűjtők és adományozók nevének hosszú felsorolása a lapok hasábjainak tekintélyes részét megtöltötte. ${ }^{15}$ Somogyvármegye Hivatalos Lapja közli azoknak névsorát, akik „sebesült ápoló és üdítő helyeket felajánlottak, teljes ellátással és gyógykezeléssel”:

$\begin{array}{lc}\text { Özv. Pallavicini Edéné örgrófné, Mosdós } & 6 \text { ágy } \\ \text { Gr. Somssich Béláné, Babócsa } & 10 \\ \text { Gr. Hunyady Károly, Somogyszil } & 30 \\ \text { Gr. Zichy Béla, Lengyeltóti } & 26 \\ \text { Gr. Széchenyi Bertalan, Felsősegesd } & 12 \\ \text { Márffy Emil, Kaposvár } & 6 \\ \text { Makfalvay Géza, Kiskorpád } & 1 \\ \text { Gr. Somssich László, Kaposújlak } & 9 \\ \text { Br. Inkey József, Iharosberény } & 10 \\ \text { Br. Inkey Pál, Iharos } & 20\end{array}$

(ez lett az Ágnes Kórház, 8 szobával,

6 önkéntes, 1 hivatásos ápolónővel és orvossal)

Dr. Goszthony Mihály, Bárdibükk 12

Rónaszéki Trux Hugó, Jákó 10

Bartha Emil, Somodor 20

Hencz Gyula, Gerézd 6

Meller Henrik, Csurgó 2

Lengyel Pál, Kaposvár 6

Gyurkovits Dezső, Kaposvár 1

Isteni Szeretet Zárda, Berzence 30

(2 szoba)

Satzger-uradalom, Ádánd 6

Szentimrei földmívesiskola $\quad 40$

Halápi Oszkár (Böhönye), özv. Hertelendy Andorné, özv. Paizs Mihályné, Vörös Lajosné, Hetyey Lajosné (Csákány), Véssey Lajos (Szöcsény), Véssey Ferenc (Szőkedencs)

„több” ágy

Csupán az élelmezési költség megtérítése mellett felajánlottak:

Tab község 100

Ádánd $\quad 50$

Balatonboglár $\quad 50$

Nagyatád 48

Babócsa $\quad 40$

Felsősegesd 40

Kiliti-Vilmatelep $\quad 26$

Bárdibükk 12

Hedrehely $\quad 10$

Juta 5

Hetes 5

Csombárd 2

Bodrog 2 ágyat

Összesen: 13 község 390 ágyat $^{16}$

15 A számtalan példa közül csak kettő: augusztus 2-án Somssich László gróf 1000 koronát adományozott a vöröskeresztnek, 4-én Szenna és Patca három nagy szekér kenyeret küldött a kaposvári állomásparancsnokságra, a katonák közötti szétosztásra. A legkisebb adományokat is közlik, legyen az 10 tojás vagy 4 üveg lekvár, 5 lavór, 2 körömkefe. Az adományok összesítését a későbbiekben mutatom be.

16 600/17682/24257/1914. kgy. sz. alispáni évnegyedes jelentés; Somogyvármegye Hivatalos Lapja, 1914. november 19. 853-854. A közölt adatok eltérnek a később közlendő kimutatástól, mert közülük többen nem a vöröskereszt keretei között tevékenykedtek. 
A hadsereg egészségügyi intézményein túlmenöen a vöröskereszt, a különféle egyesületek, egyházak, helyhatóságok, magánszemélyek is tartottak fenn a hátországban sebesült és beteg katonák ellátására szolgáló „intézményeket”, ellátóhelyeket.

Az önkéntes felajánlási gyakorlatot a hadügyi igazgatással szorosabb kapcsolatban álló formára váltotta az egyesület. Szükséges volt ez, mert be kellett illeszkednie a hadsereg katonai szervezetébe, ami által megvalósulhatott a katonai vezetés és a föként polgári elemekből álló, a magyar társadalom anyagi áldozataiból létesült Vörös Kereszt Egyesület közös munkálkodása. A hivatalos terminológia a kórházfenntartókat ajánlattevőknek, a kórház létesítésére vonatkozó ígéretet ajánlatnak nevezte. Az ellátóhelyek feladatuk szerint lehettek tartalék- és kisegítő kórházak, üdülőhelyek vagy üdülőházak, betegnyugvó állomások, üdítőállomások. Célszerü az egyes típusok vázlatos ismertetése, mert a fogalmak - a különféle tudósításokban, kimutatásokban és különösen a közbeszédben használva őket - értelmezési zavarokat okoztak.

I. A megyében tartalékkórház nem működött

II. Kisegítő kórházak

Befogadóképessége 100 ágynál kevesebb. A kisegítő kórházak tartozékai:

- mütőasztal-mütőszoba (csak az A típusnál),

- kötözőszoba (a B és a C esetben),

- orvosi felszerelés tárolására szolgáló helyiség.

Élelmezésre a honvédség biztosított személyenként 1 korona 83 fillér keretet. (Ez az összeg a későbbiekben növekedett.) A személyzethez a hadvezetés néhány népfelkelő ápolót adott, és kimondta, hogy legalább egy önkéntes vizsgázott ápolónőt kell biztosítani.

Három típusa (csoportja) van:

A/ Csak sérültek kerülnek oda. Olyan állandó orvossal rendelkezik, aki jártas kisebb mütétek elvégzésében.

B/ Könnyü sérültek elhelyezésére. Itt csak „kezelő” orvosok vannak, sebészi, mütéti tevékenység nélkül. C/ Lábadozó sérültek és betegek, meghatározott időnként „látogató” orvossal.

III. Üdülőhelyek

Lábadozó sebesültek, könnyebb betegek részére. Mütőeszköz nélküli, egyszerübb intézmény. Személyzete néhány vöröskeresztes ápolónő, feladatuk lényegében a felügyelet. Ha a felajánló száz sebesültet el tudott helyezni, akkor a katonai hatalmat képviselő „ügyeletes tiszt” kérésére az üdülöhely üdülőházzá vált.

IV. Betegnyugvó állomások

Nagyobb vasúti csomópontokon az átutazó sebesültek számára egy éjszakára vagy nappalra, továbbszállításukig nyugvóhelyül szolgálnak. A háború későbbi szakaszában - kényszerből - átalakították őket hosszabb kezelések végezhetőségére. Két típusuk volt a helyi lehetőségek függvényében: 12 vagy 200 ágyas.

\section{V. Üdítőállomások}

Egy-egy vasúti állomáson az átutazók ellátására „üdítőszolgálatot” hoztak létre: itallal (tejeskávé, tej, tea), szivarral, dohánnyal és levelezőlapokkal látták el őket.

A betegnyugvók és az üdítőállomások fogalma a tudósításokban különösen gyakorta keveredett. ${ }^{17}$

A magánszemélyek által saját erőn alapuló felajánlott (kezdeményezett) intézmények létesítéséhez első lépésben a Vöröskereszt Központi Igazgatóságától kellett engedélyt kérni. Ha támogatta, akkor az továbbította a Honvédelmi Minisztérium nevében eljáró cs. és kir. 4. hadtestparancsnoksághoz, ahol megszületett a döntés. Feltételek voltak: kőépület, folyóvízzel való ellátottság (előírás, hogy ágyanként és személyenként 160-200 liter víz álljon rendelkezésre). Egy helyiségben harminc ágy lehetett, de ágyanként $4 \mathrm{~m}^{2}-\mathrm{t}$ kellett biztosítani. ${ }^{18} \mathrm{~A}$ két megyei lap, a Somogyi Hírlap és a Somogyvármegye olyan ellátóhelyekről is tudósít, amelyek sem a hivatalos vármegyei közlönyben, sem a vöröskereszt központi nyilvántartásában nem szerepelnek. Példaként: Igalban szeptember 8-án volt az alakuló ülés a katolikus kör helyiségében. Mintegy százan voltak, mind be is léptek. Szervezte Kollár Lajos járásorvos, elnök: Hukk György esperesplébános. Felajánlották, hogy 25 könnyebb sebesültnek adnak helyet és teljes ellátást magánházakban. ${ }^{19}$ Két nappal később Nagyatádról jelentik, hogy a méntelepi kaszárnyát hetvenágyas „üdülőteleppé rendezték be”, és 8000 koronát gyűjtöttek össze. ${ }^{20}$ Ugyanekkor kelt a somogyszili tudósítás, mely szerint „a községi iskola két tantermét gyüjtés útján kórháznak rendezték be”. ${ }^{21}$ Gaál Gaszton Bogláron lakásában nyolc ágyat, a négy villájában húsz ágyat és ápolást ajánl fel ${ }^{22}$ (1. ábra).

„Köröshegyen 60 személy befogadására kórházat rendeztek be, melyhez Brüll balatonföldvári nyaralótulajdonos a nyaralóját engedte át. A nyaralótulajdonos minden szobát újságokkal, szivarral, cigarettával látott el, felesége pedig a katonaszállítás alkalmával a katonák élelmezése körül fejtett ki tevékeny, elismerésre méltó munkát. A kórházhoz szükséges kötöző anyagokra Tolnai Jenő, az Atlantic rt. vezérigazgatója 250 k-t adományozott. A kórház berendezése körül fáradhatatlan tevékenységet fejt ki Molnár Elek dr. kőröshegyi körorvos."24

17 Brüll 1984: 58-59.

18 A Magyar Szent Korona Országos Vörös Kereszt Egyletének 1914-1919. évi jelentése. Budapest, 1921. Az Országos Közgyűlés jegyzőkönyve, 1921. január 14. XXI. p.

19 Megalakult a vöröskereszt igali fiókja. Somogyi Hírlap, 1914. szeptember 12. 3.

20 Nagyatád nagylelküsége. Somogyi Hírlap, 1914.szeptember 10. 3.

21 Somogyszil a sebesültekért. Uo.

22 Balatoni villák a vöröskereszt szolgálatában. Somogyi Hírlap, 1914. augusztus 14. 3.

23 A közleményben bemutatott valamennyi felvétel a Balaton (a Balatoni Szövetség hivatalos értesítője) 1915. május 1-jei számából származik. A Balatoni Szövetség 1904-ben alakult Siófokon, 1949-ben beszüntették. Lapja 1908-tól jelent meg.

24 Kórház Köröshegyen. Somogyi Hírlap, 1914. október 6. 3. 


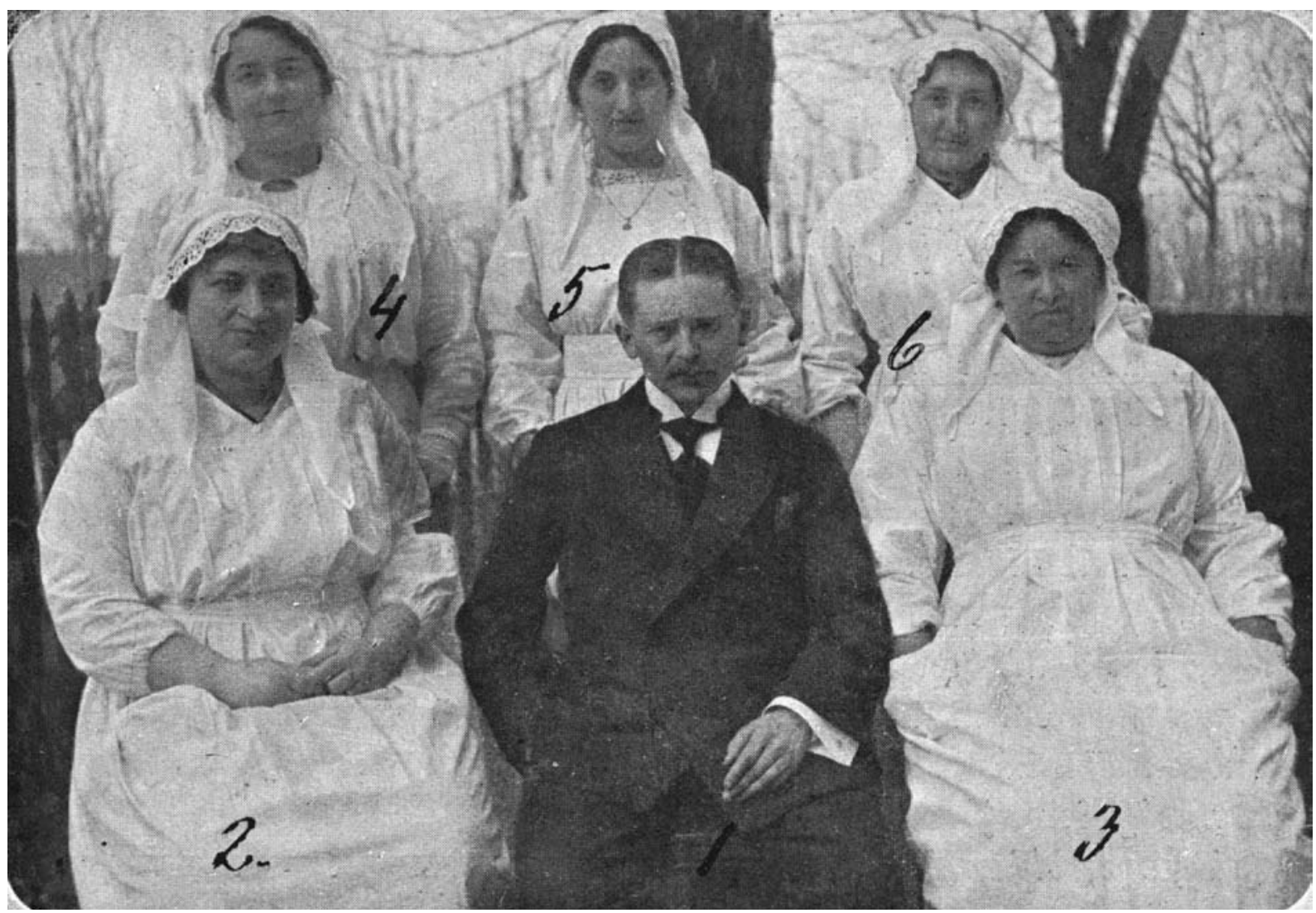

1. ábra. A balatonboglári fiókegylet vezetősége: 1. Krausz József dr. orvos,

2. Fischl Ödönné, 3. Frank Mátyásné, 4. Mahler Sámuelné, 5. dr. Lenkey Lajosné, 6. Osszeszli Antalné23

„Kéthelyen Hunyady József gróf magánkórházában elhelyezett 24 katona felgyógyult, és pár hetes szabadságra családjához utazhatott, valamennyi meleg alsóruházattal lett ellátva. Tegnap 2, ma 4 sebesült jött Nagykanizsáról, napokon belül újra 24-en lesznek."25

Barcs, Babócsa, Somogytarnóca és Belcsapuszta összesen százhúsz sebesültet lát el. Valamennyi heIyen Kapolyi Vilmos körorvos tevékenykedik, munkáját 28 helyben kiképzett önkéntes ápolónő segíti. Név szerint felsorolják öket; ünnepélyes avatásuk Somogytarnócán volt. „Annyi adomány jött össze, hogy Barcson egy gyönyörüen berendezett betegnyugvó-állomás áll a szenvedő katonák rendelkezésére" - írja a tudósító. ${ }^{26}$

Olyan esettel is találkozhatunk, amikor egy helyreigazítási kérelem vezet újabb ismeretekhez: „Somogyvármegye közgyülésén elhangzott, hogy Hunyady Károly somogyszili földbirtokos 30 ágyra állított fel kórházat, teljes ellátással a saját kastélyában. Ez téves, mert nevezett gróf úr csak 10 ágyat tart fenn,

25 Somogykéthely a katonákért. Somogyi Hírlap, 1914. október 25. 5. Említésre érdemes, hogy a gróf ebben az időben a galíciai harctéren volt, felesége pedig a budapesti vöröskeresztkórházban önkéntes ápolónő. Kéthelyen az ápolást irgalmas rendi nővérek végezték.

26 A Somogytarnócai vöröskereszt egylet ápolónő-avatása. Somogyvármegye, 1914. szeptember 23. 2 a többi 20-at pedig Somogyszil, egyes lakosainak jóvoltából, a római katolikus iskolában." Aláírás: Uradalmi intézőség ${ }^{27}$ (2. táblázat ${ }^{28}$ ).

Az első háborús év végéig országosan 2238 olyan fenntartási ajánlat érkezett be a Vörös Kereszt Egyesülethez ápolási célra történő felajánlásként, amelyet az egyesület felterjesztése alapján az illetékes katonai parancsnokság elfogadott. Ezek közül azonban a legkülönbözőbb okok miatt 516 megszűnt, illetve a katonai hatóság törölte az önkéntes betegápolási intézmények sorából. A törlések okai:

1./ katonai szempontok (irreálisan kis ágyszám, szétszórt, több telephelyes elhelyezés, katonai szabályok áthágása, menekültek részére való lefoglalás, hadszíntérré válás): 185 esetben $(35,8 \%)$

2./ egyéb okok (orosz betörés, személyi-tárgyi feltételek hiánya, anyagi gondok): 332 esetben (64,2\%)

Szólnunk kell az intézmények igénybevételéről is. Megállapítható, hogy a vöröskeresztes betegápolási intézmények sokkal nagyobb teljesítőképességűek, mint amekkora elhelyező munkát kellett végezniük. A 2238 ápolási intézmény közül 1273, tehát 56,8\%-uk egyáltalában nem kapott sebesültet. ${ }^{29}$ Természetesen

27 Hunyady gróf kórháza. Somogyi Hírlap, 1914. november 10. 3.

28 Szundy 1916: 115-148.

29 Szundy 1916: 69 
2. táblázat. A Magyar Szent Korona Országai Vörös-Kereszt Egylete által fenntartott egészségügyi intézmények 1915. augusztus 31-i állapot szerint

\begin{tabular}{|c|c|c|c|c|c|c|c|}
\hline & & \multicolumn{2}{|c|}{ Üdülőhely } & \multicolumn{2}{|c|}{ Kisegítő kórház } & \multicolumn{2}{|c|}{ Betegnyugvó } \\
\hline & & Intézmény & Före & Intézmény & Före & Intézmény & Före \\
\hline 1. & Ádánd & 1 & 50 & - & - & - & - \\
\hline 2. & Balatonboglár & - & - & 2 & 30 & - & - \\
\hline 3. & Balatonföldvár & - & - & 1 & 40 & - & - \\
\hline 4. & Balatonkeresztúr & 1 & 85 & - & - & - & - \\
\hline 5. & Balatonlelle & 1 & 24 & 1 & 60 & - & - \\
\hline 6. & Barcs & 1 & 32 & - & - & - & - \\
\hline 7. & Berzence & - & - & 1 & 30 & - & - \\
\hline 8. & Böhönye & - & - & 1 & 6 & - & - \\
\hline 9. & Büssü & 1 & 50 & - & - & - & - \\
\hline 10. & Csákány & 1 & 14 & - & - & - & - \\
\hline 11. & Csurgó & - & - & 1 & 70 & - & - \\
\hline 12. & Darány & 1 & 60 & - & - & - & - \\
\hline 13. & Felsőbűpuszta & 1 & 14 & - & - & - & - \\
\hline 14. & Felsősegesd & 2 & 12 & 1 & 39 & - & - \\
\hline 15. & Fonó & 1 & 50 & - & - & - & - \\
\hline 16. & Gyékényes & - & - & - & - & 1 & 12 \\
\hline 17. & Iharos & - & - & 1 & 20 & - & - \\
\hline 18. & Iharosberény & 1 & 10 & - & - & - & - \\
\hline 19. & Istvándi & - & - & 1 & 2 & - & - \\
\hline 20. & Jákó & 1 & 8 & - & - & - & - \\
\hline 21. & Kaposújlak & 1 & 6 & - & - & - & - \\
\hline 22. & Kaposvár & - & - & 4 & 157 & 1 & 212 \\
\hline 23. & Kazsok & 1 & 50 & - & - & - & - \\
\hline 24. & Kéthely & - & - & 2 & 122 & - & - \\
\hline 25. & Kiskorpád & - & - & 1 & 2 & - & - \\
\hline 26. & Lengyeltóti & - & - & 1 & 26 & - & - \\
\hline 27. & Marcali & 1 & 34 & 1 & 30 & - & - \\
\hline 28. & Mosdós & 1 & 16 & - & - & - & - \\
\hline 29. & Mozsgó & - & - & 1 & 24 & - & - \\
\hline 30. & Nagyatád & - & - & 1 & 80 & - & - \\
\hline 31. & Nagykorpád & - & - & 1 & 2 & - & - \\
\hline 32. & Nágocs & 1 & 4 & - & - & - & - \\
\hline 33. & Somogyszil & 1 & 10 & 1 & 35 & - & - \\
\hline 34. & Somogytarnóca & 1 & 10 & - & - & - & - \\
\hline 35. & Szigetvár & - & - & 3 & 164 & - & - \\
\hline 36. & Szőcsénypuszta & 1 & 6 & - & - & - & - \\
\hline 37. & Szőkedencs & 1 & 4 & - & - & - & - \\
\hline 38. & Tab & 1 & 50 & - & - & - & - \\
\hline 39. & Törökkoppány & - & - & 1 & 50 & - & - \\
\hline 40. & Zákány & - & - & 1 & 10 & - & - \\
\hline Összesen: & & 23 & 599 & 28 & 999 & 2 & 224 \\
\hline
\end{tabular}

ez a „kihasználtsági arány” később jelentősen változott, különösen a frontokról származó fertőző megbetegedések elszaporodásával. Jellemzőként említhetjük, hogy a háború kitörésekor a 44-esek kaposvári csapatkórházában mindössze három kórterem állt rendelkezésre fertőző betegek elhelyezésére.
1914. augusztus 14-én a föispán felhívást tett közzé, hogy a király születésnapján megtartandó „katona-napon" (augusztus 18.) a gyermeknap mintájára a hadbavonultak családjai javára mindenütt rendezzenek gyüjtést, és a helyi elöljárók tevékenyen müködjenek közre a sikeres lebonyolításban. Ennek nyomán 78137 korona 77 fillér folyt be, amelyböl az országos központhoz 11461 korona 26 fillért továbbítottak. 
A segélybizottságok gyűjtésének eredménye járásonként: ${ }^{30}$

$\begin{array}{lcc}\text { Barcsi járás } & 4286 \text { korona } & 10 \text { fillér } \\ \text { Csurgói } & 5528 & 86 \\ \text { Igali } & 2256 & 93 \\ \text { Kaposvári } & 9602 & 46 \\ \text { Marcali } & 6292 & 85 \\ \text { Nagyatádi } & 4632 & 21 \\ \text { Szigetvári } & 4553 & 55 \\ \text { Tabi járás } & 5184 & 64 \\ \text { Kaposvár város } & 17684 & 51\end{array}$

Támogatás nem csak akciós gyűjtésekből érkezik: Somogy Vármegye Törvényhatósági Bizottságának javaslatára a vármegye 20000 koronát a sebesültek ápolására ad át az ebadóalapból. ${ }^{31}$

A helyi újságok folyamatosan közlik a felajánlásokat és az adakozók névsorát. Nem lehet célunk ezek tételes ismertetése, helyette néhány nagyobb fiókegylet összesített adatait mutatjuk be (3. táblázat ${ }^{32}$ ). Az arányok és a tényleges „vásárlóérték” megítélhetőségéhez segíthet az aktuális árak ismerete.

$\begin{array}{ll}\text { Élelmiszerárak a Balatonnál (maximált): } & 33 \\ \text { tyúk }(\mathrm{db}) & 3-4 \text { korona } \\ \text { hízott liba }(\mathrm{kg}) & 2,80-3 \text { korona } \\ \text { házi vaj }(\mathrm{kg}) & 4 \text { korona } \\ \text { tej kimérve (liter) } & 24 \text { fillér } \\ \text { tojás }(\mathrm{db}) & 8-10 \text { fillér }\end{array}$

A teljes megyére érvényes fogyasztói húsárak: ${ }^{34}$ sertéshús $(\mathrm{kg}) \quad 7$ korona 20 fillér nyers vagy füstölt sonka $\quad 8$ korona olvasztott zsír 8 korona 60 fillér elkészített szalonna, sózott 8 korona húsos kolbász 9 korona

A búzából készült finom tésztaliszt és dara maximális ára mázsánként 95 korona 50 fillér, a kenyérliszt 41 korona 47 fillér, a rozsliszt 45 korona 85 fillér. ${ }^{35}$

A megyei választmány még 1916 decemberében is folyamatosan szorgalmazta további fiókegyesületek létrehozását. A tényleges iratanyagra, a válaszokra, további történések dokumentumaira nem leltem rá. ${ }^{36}$ Kivételt képeznek ez alól Csurgó (töredékes ismeretek), Balatonlelle és Szigetvár. Utóbbi kettő közgyülési

30 Somogyvármegye Hivatalos Lapja, 1914. november 19. 853.

31 Somogymegye a sebesültekért. Somogyvármegye, 1914. november 5.3 .

32 Szundy 1916: 90-91., 190-233. A *-gal jelölt helyeken az adatok hiányoznak. A természetbeni adományok korona értékének megállapítása során a kimutatások számadatai ellentmondásosak.

33 Élelmiszerárak. Somogyi Hírlap, 1915. június 24. 4.

34 Az alispán maximálta a megye területére a sertéstermékek árát. Somogyi Hírlap, 1916. július 16. 2.

35 A búza és a rozsliszt maximális ára. Somogyi Hírlap, 1916. július 22. 3.

36 MNL SML X. 202. Somogyvármegyei választmány iktatókönyve. Megnyitva: 1916. október 3. A felszólítások december 24-i kiküldési dátumokkal szerepelnek. Címzettek (a bejegyzés sorrendjében): Karád, Babócsa, Attala, Nagyszakácsi, Tótszentpál, Kötcse, Ságvár, Balatonszentgyörgy, Andocs körjegyzőségei. és választmányi üléseinek jegyzőkönyvei hiánytalanul látótérbe kerültek. A belölük megismerhető küzdelmes és áldozatos müködés feltehetően valamennyi egyesületre jellemző lehetett.

A csurgói fiókegylet 1890-ben alakult, ennek ellenére működéséről az első híradás csak 1914 novemberében volt olvasható. ${ }^{37}$ Elnöke Mohar József állami tanítóképző intézeti igazgató, orvosa dr. Éhn Kálmán járási főorvos. Megalakulásával egyidejüleg nyitotta meg kórházát október 9-én nyolc felvett beteggel a református fögimnáziumban, Folenta Lajosné főápoló vezetésével. Az ápolásban rajta kívül öt önkéntes és két fizetett hivatásos ápolónő vett részt. Az élelmezést tizenegy tagú hölgybizottság intézte három kisegítővel (kézilány, mindenes, mosogató). Kimutatásuk szerint 1916. április közepéig 480 beteget vettek fel 21485 ápolási nappal, továbbá 65 átutazó katonát. Akkor hetven ágy állt rendelkezésre. A legnagyobb létszám 1915 áprilisában volt, akkor négy pótágyat kellett beállítani. A 480 betegböl távozott 429, az ápoltak száma 51. A távozottak közül gyógyult 378, javult 49. El kellett küldeni rossz magaviselet miatt 1-et, csapatkórházba került 1 . Mütét 56 volt: lövedékeltávolítás, fagyás miatti végtag-eltávolítás. Az összes bevétel 57013 korona, a kiadás 48252 korona. Kitüntetések: Mohar József és Éhn Kálmán hadiékítményes II. oszt. díszjelvényt, 5 tag ezüst díszérmet, a főápoló bronzérmet kapott ${ }^{38}$ (2. ábra).

Siófokon 1914. november 8-án alakul meg a fiókegylet 200 taggal, dr. Ney János orvos elnökletével. Vállalásuk szerint a nagyobb villákban összesen 80-90 sebesült ellátásáról gondoskodnak. A Takarékpénztári Igazgatóság tíz sebesült számára „négy szobából álló lakást" rendezett be. A vak katonák részére szervezett gyűjtés 300 korona eredményt hozott ${ }^{39}$ (3 és 4 . ábra).

Az előbbinél lényegesen több információt nyerhetünk a balatonlellei vöröskereszt-fiókegylet 1914-1918 közötti jegyzőkönyveiből. ${ }^{40} \mathrm{Az}$ 1914. november 8-án megtartott alakuló közgyülésen megválasztott tisztikar tagjai a helyi és az ott villatulajdonos fővárosi elit tagjai köréböl kerültek ki. Egyesületi elnök özv. Szalay Imréné (földbirtokos, szállodatulajdonos), társelnök Bartos Tivadarné (férje a Magyar Szent Korona Országai Vörös-Kereszt Egyletének megbízottjaként a megalakulás kezdeményezője, cs. és kir. kamarás, miniszteri osztálytanácsos), Álgya Papp Sándorné (vezérkari alezredesné). Alelnökök: Hónig Izidorné (nagybérlő), Hüttl Frigyes (a pesti Hüttl Porcelángyár ügyvezetője), Francois Lajos (pezsgőgyáros), Milassin Vilmosné (az ő tulajdonában volt akkor a legnagyobb, 52 szobás, későbbi Gyárfás Panzió), Zilahy Dezső (a Balatoni Yacht Club alelnöke). Titkár: dr. Breznay Béla (a budapesti Pázmány Péter

\footnotetext{
37 A csurgói vöröskereszt egylet kisegítő kórháza. Somogyi Hírlap 1914. november 3. 4.

38 Csurgói hadikórház. Somogyvármegye, 1916. április 23. 4-5.

39 Balaton 1915: 39-40. Konkrét dokumentumokkal a Deutsch-, Fischer-, Medveczky-, Rozgonyi-villákban lévő sebesültekke kapcsolatosan találkozhatunk. Érdekes módon Szundy Károly kimutatásában (Szundy 1916) Siófok nem szerepel.

40 MNL SML X. 203.
} 
3. táblázat. A fiókokhoz a mozgósítás kezdetétől 1915. augusztus 1-ig beérkezett adományok az Országos Központ nyilvántartása alapján

\begin{tabular}{|c|c|c|c|c|c|c|c|c|c|c|}
\hline & \multirow{2}{*}{$\begin{array}{c}\text { Pénzbeli } \\
\text { adományok }\end{array}$} & \multicolumn{2}{|c|}{ Ágynemü } & \multicolumn{2}{|c|}{ Fehérnemü } & \multicolumn{2}{|c|}{$\begin{array}{c}\text { Bútor és felszerelési } \\
\text { tárgy }\end{array}$} & \multirow{2}{*}{$\begin{array}{c}\text { Élelmiszer } \\
\text { korona } \\
\end{array}$} & \multicolumn{2}{|c|}{ Ruhaféle } \\
\hline & & $\mathrm{db}$ & korona & $\mathrm{db}$ & korona & $\mathrm{db}$ & korona & & $\mathrm{db}$ & korona \\
\hline Kaposvár & 58842 & 3511 & 5252 & 8417 & 3751 & 31 & 86 & 9279 & 672 & 276 \\
\hline $\begin{array}{l}\text { Szigetvár } \\
\text { és környéke }\end{array}$ & 13249 & 350 & 900 & 400 & 300 & 200 & 150 & 2000 & * & * \\
\hline Nagyatád & 5610 & * & * & 540 & 310 & * & * & 1970 & * & * \\
\hline Csurgó & 2280 & * & 400 & * & 1830 & * & 100 & 6060 & * & 350 \\
\hline Balatonlelle & 998 & 18 & 26 & 1192 & 2274 & * & 1395 & 2345 & * & * \\
\hline Köröshegy & 150 & 72 & 214 & 178 & 292 & * & * & 66 & * & * \\
\hline
\end{tabular}

\begin{tabular}{|l|c|c|c|c|c|c|c|c|c|c|}
\hline & Gyógyszer & Szeszes ital & \multicolumn{2}{|c|}{ Szivar } & \multicolumn{2}{c|}{ Szivarka } & \multicolumn{2}{c|}{ Dohány } & \multicolumn{2}{c|}{ Egyéb tárgy } \\
\hline & korona & korona & $\mathrm{db}$ & korona & $\mathrm{db}$ & korona & $\mathrm{db}$ & korona & $\mathrm{db}$ & korona \\
\hline Kaposvár & 10 & 1193 & 605 & 34 & 11520 & 229 & 119 & 15 & 1619 & 1900 \\
\hline $\begin{array}{l}\text { Szigetvár } \\
\text { és környéke }\end{array}$ & $*$ & 250 & $*$ & 50 & $*$ & 50 & $*$ & 250 & $*$ & 300 \\
\hline Nagyatád & $*$ & 95 & 200 & 24 & 16400 & 328 & 90 & 7 & ${ }^{*}$ & $*$ \\
\hline Csurgó & $*$ & 100 & $*$ & 300 & $*$ & 200 & $*$ & 40 & ${ }^{*}$ & 1000 \\
\hline Balatonlelle & 8 & 367 & 250 & 10 & 14490 & 147 & 36 & 27 & ${ }^{*}$ & $*$ \\
\hline Köröshegy & 177 & 150 & 550 & 60 & 2100 & 18 & ${ }^{*}$ & 60 & ${ }^{*}$ & $*$ \\
\hline
\end{tabular}
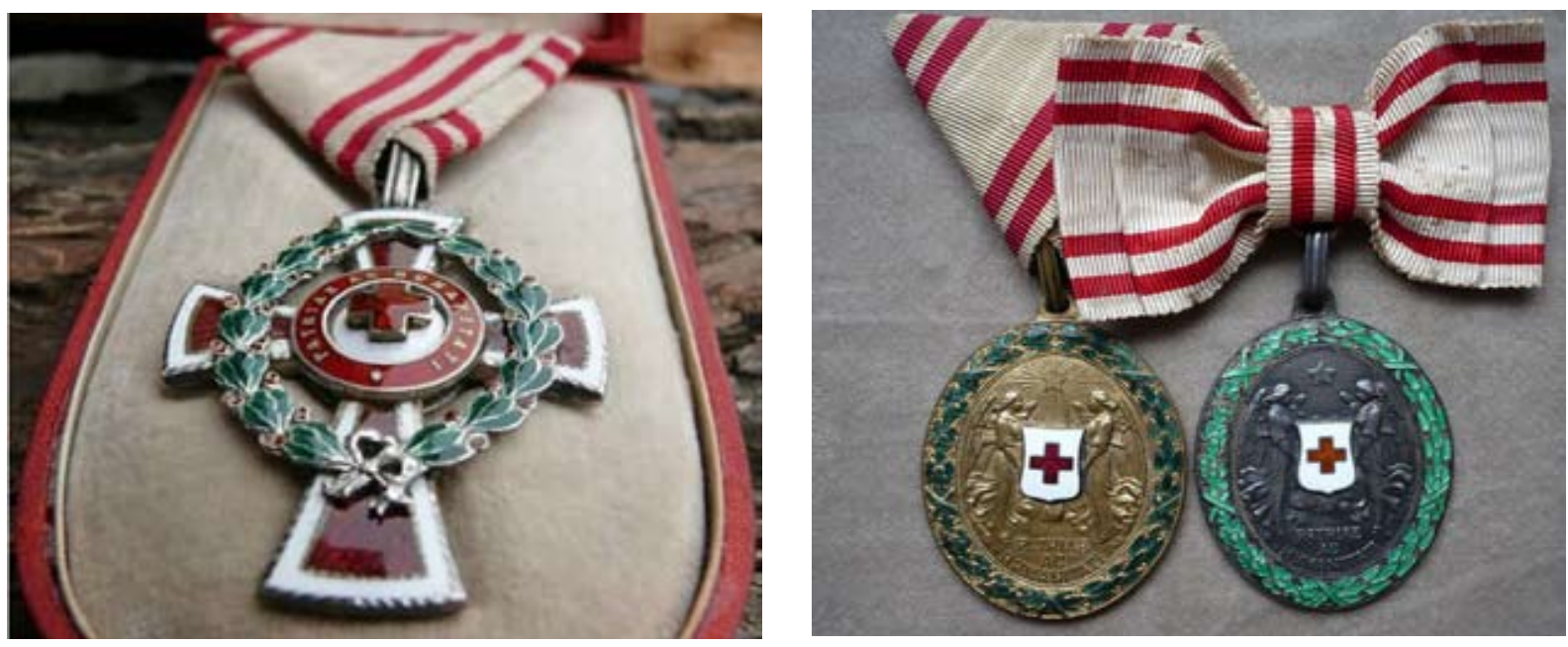

2. ábra. Baloldalt a hadiékítményes II. osztályú díszjelvény, jobbról az ezüst és a bronz díszjelvények

Tudományegyetem erkölcstantanára, majd rektora.) A december 6-i rendkívüli közgyülés idején már 165 tagja van. Különleges helyzetéből, a tehetősebb tagság összetételéből adódóan valamennyi megyei fiókegyesülettől eltérő, magasabb alapítói összegeket fizettek be. Egy 100 koronás, három 50 , tizenhárom 40 koronás alapító; húsz 20 koronás, százhuszonhét 2 koronás rendes és egy 1 koronás rendkívüli tag alkotta a létszámot. Részlet a jegyzőkönyvből: „Egyesületünk megalakításával céljául tűzte ki egy kisegítő kórház létesítését. A célt, amint már Önök is tudják, a legteljesebb mértékben meg is valósítottuk. [...] Létesítettünk egy olyan kórházat, amelynek párját kényelem és tisz- taság, szépség és élelmezés dolgában vidéken alig találjuk. [...] Kórházunk 60 sebesültre van berendezve, s fenntartásához naponta érkeznek jószívű adományok"41 (5. ábra).

41 A kórház 1914. november 27-én kezdte meg müködését az 1905ben felépült, szabadkőműves-kezdeményezésre és fenntartásukban tevékenykedő Szünidei Gyermektelep-hálózat balatonlellei telephelyén. („Egy magaslatról a Balatonra tekint. Két nagyméretű kórterme van, könnyen elfér benne a hatvan személy. Az ebédlő egyben társalgó is. Nagyméretű mosdók és a személyzetnek is szép helyiségek állnak rendelkezésre. Árnyas udvarkerttel, mellék épületekkel, nagy konyhával rendelkezik." Somogyi Hírlap, 1915. április 18. 2.) A háborút és a páholyok feloszlatását követően a Belügyminisztérium tulajdonába került, 1936-ban az Országos Gyermekvédelmi Ligának adták át. Horváth 1943: 130. 


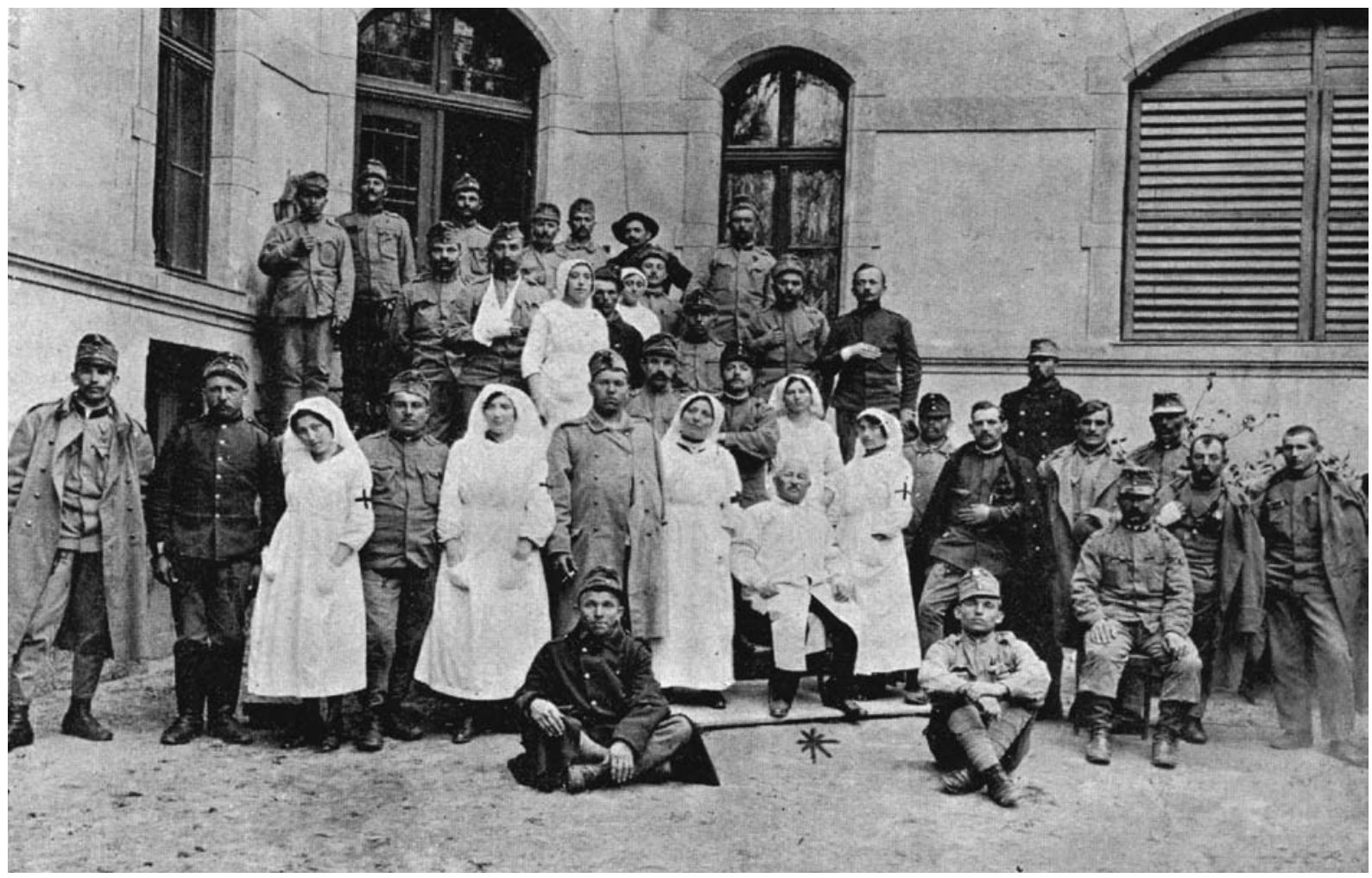

3. ábra. Siófok: a Deutsch-villában elhelyezett beteg katonák és az ápolónők. Középen *-al jelezve dr. Ney József orvos

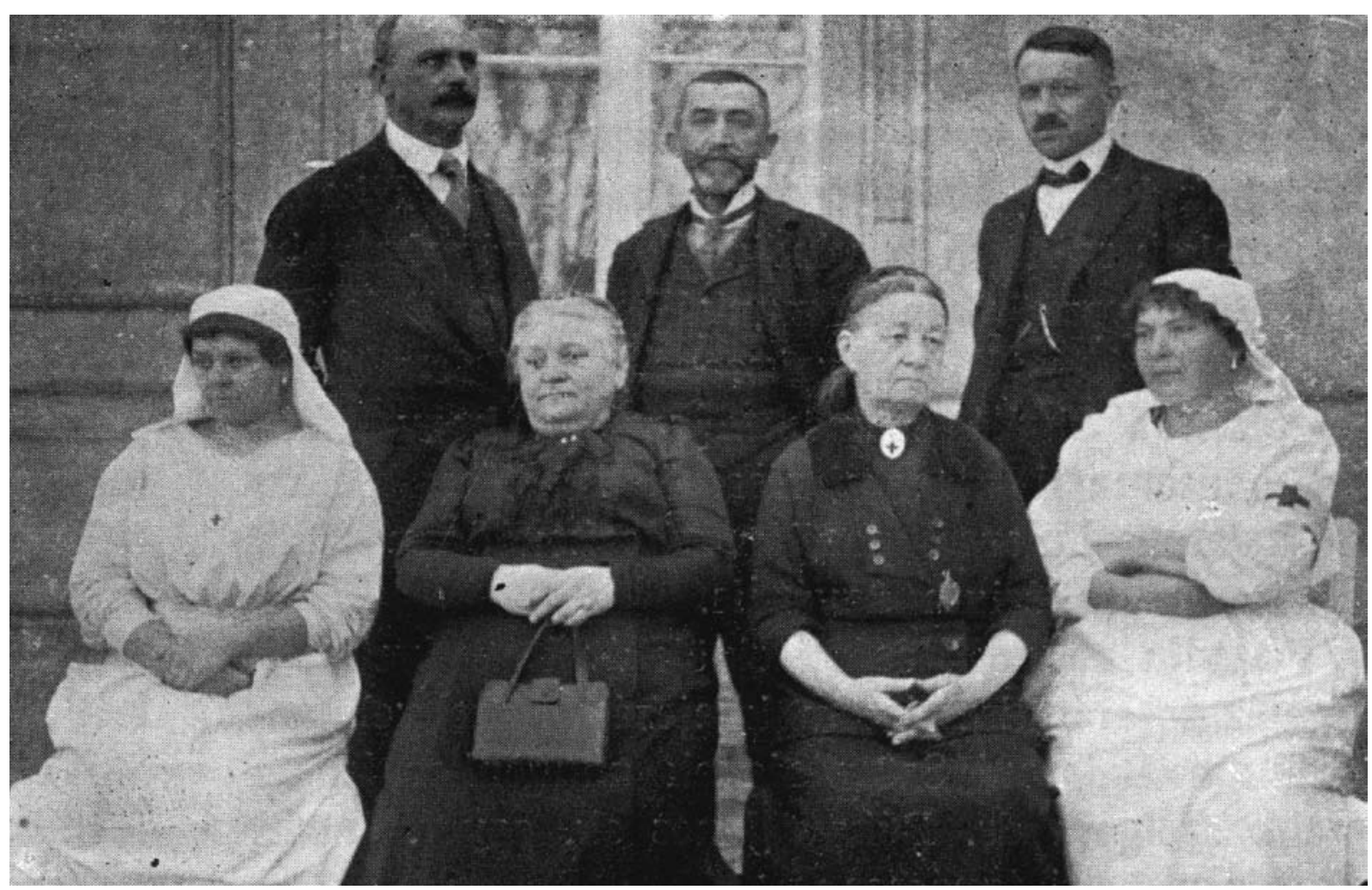

4. ábra. A balatonlellei fiókegylet vezetösége: (balról-jobbra) Álgya Sándorné, özv. Szalay Imréné, Kempelen Gyuláné, Harrer Paulina. Állnak: Erker András, dr. Lisznyay Elemér, Körmendy Péter 


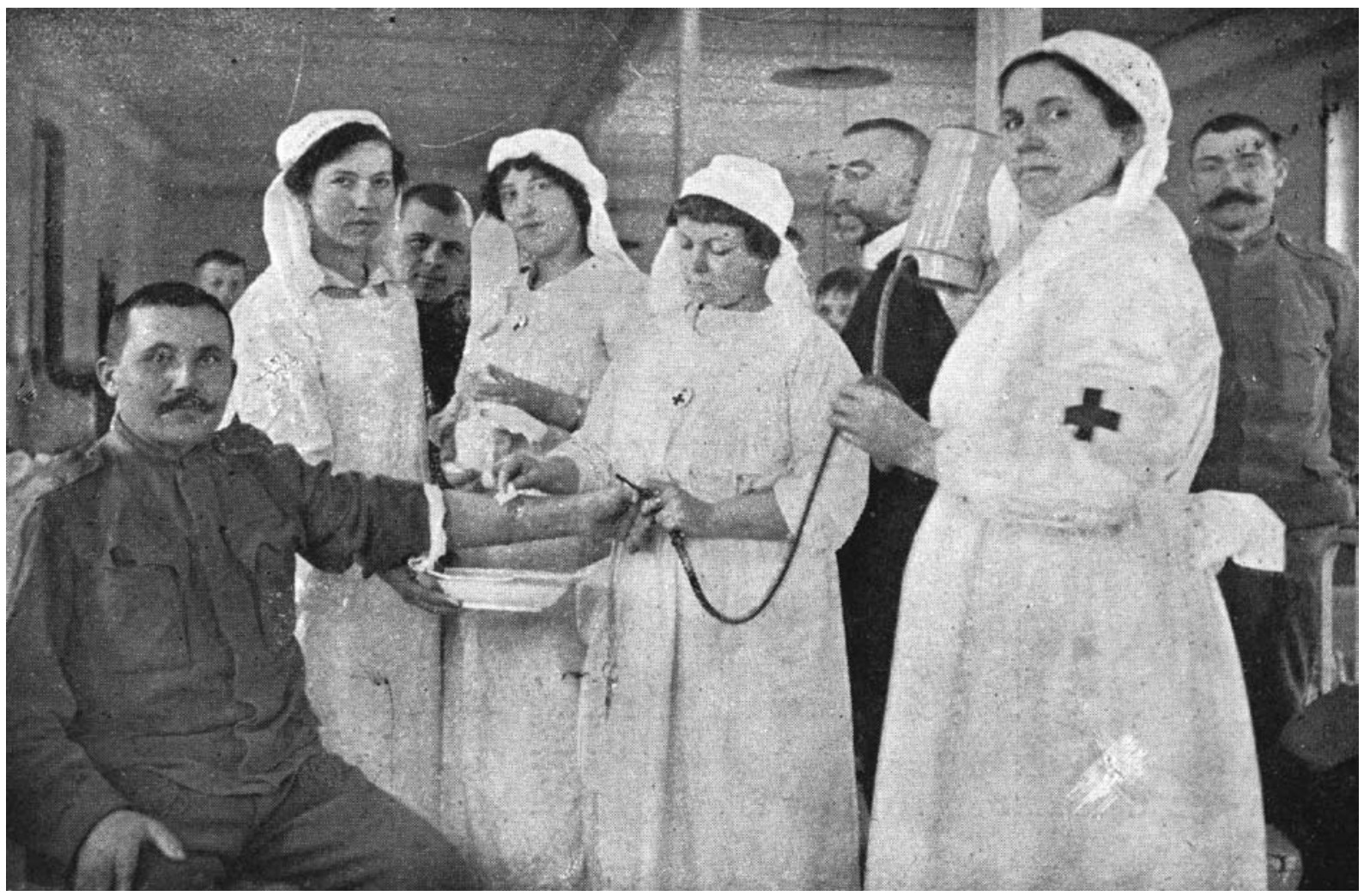

5. ábra. A balatonlellei fiókegylet ápolónői betegellátás közben

A fejlődés töretlen, az 1914. évi évzáró közgyűlésen újabb 25 csatlakozóval 191-re bővül a létszám. A megalakulást követően egy hónap alatt 94 sebesültet ápoltak, közülük 52 távozhatott is (6. ábra).

Az 1915-ös év adatai tiszteletre méltóak. A taglétszám már 200, a kórházba 1914. november 27-től 1915. december 31-ig 447 sebesült, illetve beteg katonát vettek fel, haláleset nem fordult elő. Az ápolási napok száma meghaladja a tizenhatezret. A természetbeni felajánlások értéke 4452 korona 84 fillér.

A fiókegyesület tagjai közül számosakat tüntettek ki munkájukért, özv. Szalay Imréné elnöknő, az egyesületi orvos (dr. Lisznyai Elemér), két föápolónő és a tagság sorából további két személy a vöröskereszt II. osztályú hadiékítményes díszjelvényét kapta, az ápolónők hét hadiékítményes ezüst- és három bronzéremben részesültek.

A háború okozta nehézségek 1916-ban már Balatonlellén is éreztetik hatásukat. A hadkiegészítő parancsnokágtól megérkezik az utasítás a húsadagok csökkentésére és az azokat helyettesítő tengeri halak étrendbe állítására. Ez az intézkedés élénk vitát vált $\mathrm{ki}$, végül szavazást követően az a határozat születik, hogy nem követik az előírást, praktikus okokból tengeri hal helyett balatonival pótolják a húshiányt.

Bajok vannak a számvitel terén, a továbbiakban - felszólításra - egymástól elkülönítve kell kezelni a kórház és a fiókegylet pénzügyeit. Egy év alatt, három pénztárosváltást követően sikerül csak megoldani a feladatot. A csökkenő felajánlások, az ápolás fedezethiányával való szembesülés már elörevetíti a hamarosan bekövetkező működési zavarokat. Az 1916. évi záró rendes közgyűlés megtartására 1917. március 11-én kerül sor. Először fordul elő kilépés (2 fő), és elöször értesülünk 27 személy esetében a tagdíjfizetés elmaradásáról. Ezek megoszlása: hároméves hátralék 2, kétéves 6, egyéves 19.

A szeptember 16-án megtartott választmányi ülésen éles vitával kísért bizalmi válság alakult ki, amelynek oka az elnöknő bejelentése, miszerint a fenntartás nehézségei miatt beadványt juttatott el a budapesti igazgatóságához a kórház feloszlatásáért. Az onnan kapott válaszban felfedezhető a malícia: a kórház „bizonyos jóakarattal” tovább müködtethető, még akkor is, „ha az elnöknő bármely okból távol lenni kénytelen". Megismételt levélváltás következik: egyrészről a feloszlatás iránti igény megerősítésével, másrészről az alapszabály szerinti működés szükségességére való utalással, miszerint csak a fiókegyesület választmányi ülése dönthet a kérdésben. Észlelve az elnöknő hajthatatlanságát, a központ elfogadja a feloszlatás tervét, és közli, hogy a kaposvári hadkiegészítő parancsnokság a kórházak névsorából való törlés után eltávolítja a katonákat.

Szembesülve a helyzettel most már a fiókegyesület kéri a kiürítés elhalasztását, arra hivatkozva, hogy még nem döntött a választmány. A titkár, dr. Breznay Béla (aki ekkor már egy személyben pénztáros és az ügyek tényleges intézője) elismeri ugyan a nehézségeket, de 


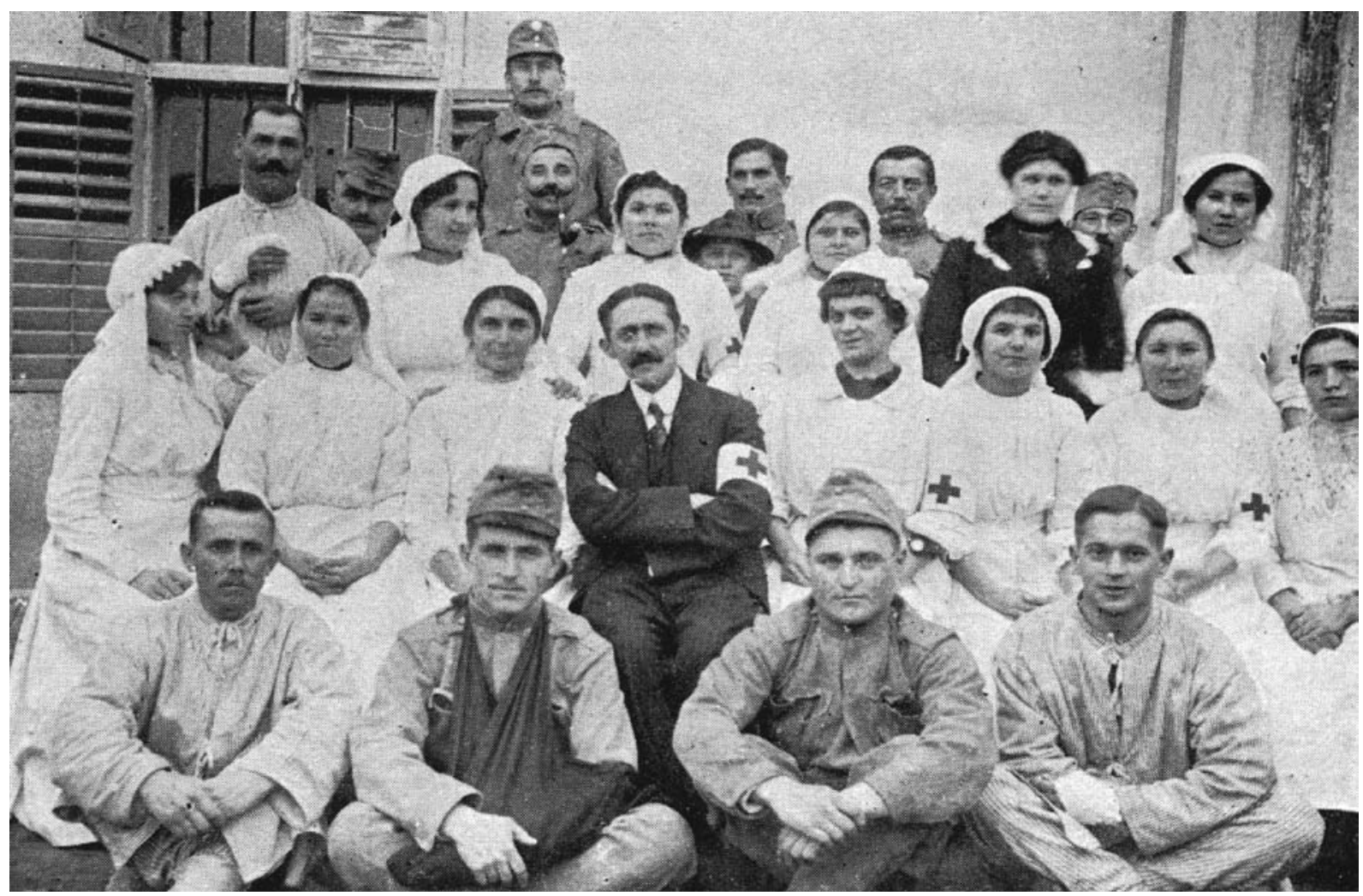

6. ábra. A balatonlellei fiókegylet ápolónői betegellátás közben

határozottan felhívja a figyelmet az elkövetett szabálytalanságokra. Hatásköri vita után kéri az elnöknőt, ne riadjon vissza a nehézségektöl, aki öntudatosan viszszautasítja a feltételezést. Végül szavazásra kerül sor: a döntés egyhangú, maradjon kórház.

A közel egyéves szünetet követően 1918. március 10-én megtartott választmányi ülésen nincs jelen az elnöknő, a tárgysorozat valamennyi pontjának elöadója dr. Breznay Béla. Elmondja, hogy a kórház müködtetésére alig van fedezet, ennek ellenére javasolja, hogy a háború várható végéig, de legkésőbb szeptemberig még fenn kellene tartani. Amennyiben a háború nem érne véget, fel kell majd kérni a katonaságot, hogy vagy ürítse ki a kórházat, vagy vegye át azt. Ma már hiányoznak a fehérnemük is, holott ezekkel ellátva kellene kiengedni az elbocsátandókat, adományok nem érkeznek.

A fiókegyleti és katonai kórházi pénztárak kezelését egy személyben végzi Breznay, amin változtatni kellene. Hiába jelenti ki: belefáradt a munkába, senki nem fogadja el a posztot. A fiókegylet jövedelme 1917-ben: tagsági díjból és azok felülfizetéséből 901 korona, jótékonysági hangverseny: 190 korona 66 fillér, összes adomány: 100 (!) korona.

A kórház pénztára hónapról hónapra haladva 67908 korona bevételt és 67729 korona kiadást mutat. A bevételi többlet csak 179 korona. Deficitközeli állapot van. Határozat: a szeptemberi választmányi ülésen fognak végleges döntést hozni a kórház további sorsáról.
Április 14-én rendkívüli választmányi ülést kell tartani, mert a központi igazgatóság kéri, hogy a budapesti Szünidei Gyermektelep részére a fiókegyesület három hónapra adja át a balatonlellei telepházukat. Két lehetőség kínálkozik: amennyiben a kórházat az 1918-19. évi téli időszakban fenntartani nem tudják, ne halasztódjon a döntés őszre (a korábbi választmányi ülés határozata értelmében), hanem már most mondja ki a kórház leszerelését, hogy ne vonja el a gyerekektöl az üdülés lehetőségét. Másik lehetőség: csak a nyári hónapokra szüneteltetik, aztán ismét működik.

A folyamatos fenntartás mellett döntenek, ezért a helyiségeket nem adják át, mert a gyermektelep ugyanúgy, mint ahogy azt az elmúlt években is megtette - Szalayné Hattyú nevü szállodáját kedvezményesen igénybe veheti.

$\mathrm{Az}$ események felgyorsulnak. Május 5-én a választmányi ülésen már a központ is képviselteti magát, hogy a személyes jelenlét meggyőző erejével bírja más döntésre az ellentmondó egyesületet. Kifejtik, harcok intenzitásának csökkenése miatt nincs már szükség ennyi ágyra - már korábban is a százágyasnál kisebb kórházak megszüntetésére történtek intézkedések -, így semmi nem indokolja a fenntartást. Ráadásul az új királynak (IV. Károly) személyes kívánsága a gyermekekkel való fokozott törődés, ezért vegye fel a személyes kapcsolatot az egyesület az uralkodóval, ha másként akarnak dönteni. Breznay és még egy társa különvéleményt fogalmaz meg, továbbra is ellenzik a 
dolgot. Indoklásuk szerint nincs is lehetősége a választmánynak dönteni, közgyülési felhatalmazás kell, ráadásul amikor a lellei ház épült, már egy esetleges háborúra való felkészülés jeleként kórház volt a cél, és nem gyermektelep.

Név szerinti szavazással 6-an a bezárás mellett, 6-an ellene döntenek. Tekintettel arra, hogy az elnöknő voksa szavazategyenlőség esetében ügydöntő, túlsúlyba kerültek a bezáráspártiak. Ezzel megpecsételődött nemcsak a kórház, hanem a Magyar Szent Korona Országai Vörös-Kereszt Egylete balatonlellei fiókjának további sorsa is.

A Szigetvári fiókegylet ${ }^{42}$ megalakulásán, 1899. június 25-én a jegyzőkönyv szerint 46-an voltak jelen, közülük tízen nem szigetvári lakosok. Ugyanezen a napon megalakítják 25 tagú választmányát. Elnöke az egylet létrehozásának kezdeményezője, Biedermann Ottóné (földbirtokos) lett. Az alelnökök Hegyessy Jánosné és Hegyessy János (szigetvári járási főszolgabíró), a jegyző dr. Kriszt Béla (ügyvéd). Tevékenysége abban az időben elsősorban jótékonysági gyűjtést célzó rendezvények megtartásából állt, mint amilyen például „tánccal egybekötött tombolaest megrendezése a Koronában". A taglétszám növekszik, 1902. december 31-én már 126 fö.

1904 és 1914 közötti müködésének nincsenek nyomai. Tízéves szünetet követően, 1914. február 15én dr. Rusa Ernő (közjegyző, országgyűlési képviselő) megbeszélést hívott össze az újraalakulás előkészítésére. A jegyzőkönyv tanúsága szerint egy felszólaló kifejtette, hogy nem alakuló ülést kell tartani, mert a fiókegylet egyszer már megalakult, és nem megszűnt, csak nem müködött. ${ }^{43}$ Dr. Rosenberger Alajos, a szigetvári közkórház sebész képzettségű főorvosa bejelenti önkéntes ápolónői kar létrehozását és tanfolyam indítását, amelyre 15-en jelentkeznek.

1914. március 15-én tartják meg az újraalakuló ülést, amelyen 51-en jelentek meg. Elnökké közfelkiáltással dr. Rusa Ernőnét választották meg. Fontos téma volt, hogy az egylet korábban (1904-ig) gyüjtött 754 korona 49 fillér vagyonát - amely a megyei választmány pénzeszközei között szerepel - az alispán segítsen kiadni. Ez a tény is a folytonosság bizonyítékaként értelmezhető. Ugyanezen a napon megválasztották a 24 tagú választmányt, amelynek elnöke gróf Hoyos Miksa lett. A női társelnök dr. Rusa Ernőné, az alelnök Hegyessy János, a női alelnök Hegyessy Jánosné, a titkár dr. Kriszt Béla, az orvos dr. Rosenberger Alajos. Jelen ismereteink szerint nincs még egy olyan vidéki választmány, amelynek tisztikara a fiókegylet teljes müködési idejében személyi változás nélkül maradt volna. Augusztusra visszakapták a kérelmezett vagyont, és tizenhárom önkéntes ápolónő, aki sikeresen elvégezte a tanfolyamot, átvette bizonyítványát.

42 MNL SML X. 204. Magyar Szentkorona Országainak VörösKereszt Egylete Szigetvári Fiókjának iratai.

$43 \mathrm{Az}$ okfejtésnek helyt adva a szigetvári fiókegylet megalakulásának időpontjaként 1899. június 25-ét fogadhatjuk el.
Dr. Rosenberger Alajos a választmányi ülésen elöadja: a „Magyar Szent Korona Országai Vörös-Kereszt Egylete Igazgatósága felhívta a szigetvári közkórházat, hogy a még 1902-ben a közkórház részéről tett ígérete alapján 20 sebesült katona részére ágyat és 20 üdülő beteg katona részére helyet és ellátást tartson készen, mert a jelenlegi háború alatt azt igénybe fogja venni. Indítványozza, hogy a szigetvári közkórházba érkező beteg katonák részére szükséges kötszereket a vöröskereszt szigetvári fiókja szerezze be és bocsájtsa rendelkezésére." A határozat: a fiók 500 koronát ad, egyúttal felkéri dr. Rosenbergert a beszerzés lebonyolítására. Gróf Hoyos Miksa és gróf Erdődy Rudolf kizárólagosan az egylet céljára 1000-1000 koronás alapítványt tettek. (Hálából „örökös” alapító tagként nyernek felvételt.) Kisebb összegeket mások is adnak. Bővül a létszám, öt új tagot vesznek fel hat éven át évi 2 korona tagdífizetési kötelezettség vállalásával.

Felolvassák gróf Erdődy Rudolf levelét, amelyben indítványozza, hogy a fiókegylet 20-30 beteg katona részére betegnyugvó állomást létesítsen, amelyre a polgári fiúiskolában helyiség állna rendelkezésre. Dr. Rosenberger az indítványt ellenzi, mert a szigetvári közkórházban 40, a város egyes lakosainál, a környék nagybirtokosainál is mintegy $15-20$ beteg és további 30 üdülő katona nyerhet elhelyezést, így a betegnyugvó állomásra még szükség nincsen. Dr. Kriszt Béla titkár javasolja, hogy egyelőre csak tervezetet készítsenek a betegnyugvó költségeinek megállapítására, ennek megtörténtével lesz módja a választmánynak dönteni a kérdésben. Határozat: háromtagú bizottság készítsen költségvetést 10-15-20-30 beteg katona részére létesítendő betegnyugvó állomás előrelátható költségeiről.

A szeptember 1-jei választmányi ülésen terjeszti elő a kiküldött bizottság a kalkulált költségekkel kapcsolatos jelentését, amely szerint 30 legénységi állományú beteg részére ágyak beszerzése nélkül 1108 korona, 20 beteg számára 850 korona, 10 beteg számára 550 korona lehet a kiadás. Az élelmezés, mosás, felügyelet naponként és fejenként 2 korona 20 fillérre tehető. Elhelyezésére az olvasóegylet nagyterme felelne meg. A választmány határozata: „20 legénységi állományú sebesült vagy beteg katona részére összesen 1200 ápolási napon át betegnyugvó állomást létesít, és azt minden szükségessel felszereli, olyképp, hogy az szükség esetén kisegítő kórház céljára is felhasználható legyen. Felkéri a szigetvári Olvasó egylet elnökségét, hogy fenti célra nagytermét, könyvtárszobáját, a mellette lévő mellékhelyiséget a fiókegylet rendelkezésére bocsátani szíveskedjék. Felkéri a központi igazgatóságot, hogy a felügyelet és rend fenntartására megfelelő személyzetet kirendelni szíveskedjék, és amennyiben kisegítő kórház céljára használtatik a nyugvó állomás, 1 hivatásos ápolónőt is adjanak. A felmerülő összes kiadások fedezésére a pénztárból 3000 koronát folyósít." Felhívást ad ki gyűjtésre, ami kiemelkedő eredménnyel jár, a berendezés zömét sikerül adakozásból beszerezni, ennek következtében több ezer koronát megtakaríthatnak, amelyet majd a működtetésre lehet 
fordítani. A legnagyobb adakozók: gróf Hoyos Miksáné, gróf Erdődy Rudolf és özv. Biedermann Ottóné, akik egyaránt 1000-1000 korona készpénzzel, illetve berendezési tárgyak, ágyak, harminc szalmazsák (mind Hoyosné), evőeszközök, varrószerek, köpőcsészék stb. felajánlásával segítettek. ${ }^{44}$

A szeptember 20-i választmányi ülésen bejelentik, hogy három hónapra ingyen, azt követően fejenként és naponként 2 korona ellátási díj fejében felállítják a kisegítő kórházat. Jelenleg már 25 ágy van „teljesen felszerelve", a többiek is rendelkezésre állnak a gyűjtés eredményeként. Az élelmezés a szigetvári közkórház konyhájáról történik. Kérik az orvost az ápolónők beosztásának elkészítésére, köszönetet mondanak a polgári fiú- és leányiskola tanárainak és növendékeinek a katonák kiszolgálására, ruhafoltozásra, tépéskészítésre tett vállalásaikért. A két ápolónői tanfolyam vizsgázott hallgatói leteszik fogadalmukat, összesen 40-en vannak. A taglétszám 17 új, évi kétkoronás rendes taggal bővül.

A december 17-én megtartott választmányi ülésen betegforgalmi összesítésekkel találkozunk. Szokatlan módon az éves számadásokat a megszokottól eltérően nem az év végi (december 31-i) állapotnak megfelelően végezték el, ami aztán a következő év során nehezen követhető korrekciókat igényelt. Ezeknek részletező követése kívül esik célunkon.

1914. szeptember 26-tól december 31-ig: 120 ellátott, 2711 ápolási nap

1915. január 1-től december 15-ig:

$\begin{array}{lll} & 380 & 11628 \\ \text { Összesen: } & 500 & 14339\end{array}$

1915. évi bevételek (január 1. - december 15.), tagdíjak és föleg adományok:

$\begin{array}{lll} & 11812 \text { korona } & 62 \text { fillér } \\ \text { Kiadás: } & 12927 \text { korona } & 43 \text { fillér } \\ \text { Összes hiány: } & 1114 \text { korona } & 81 \text { fillér }\end{array}$

A hiány az elmúlt évi maradványból (3939 korona 95 fillér) lett pótolva, ennek alapján pénztári kezelés alatt áll 2825 korona 14 fillér

Határoznak a saját és a közkórházban lévő katonák karácsonyi megajándékozásáról. Ünnepélyt rendeznek december 22-én, ennek bevételéből vesznek kisebb használati tárgyakat. Megelőlegeznek erre 250 koronát.

A vállalt három hónapos díjtalan fenntartás mellett ebben az évben is sikerült térítés igénylése nélkül fenntartani az üzemeltetést, de már látszik, hogy csökkennek az adományok, és drágul minden élelmiszer (a müködést már szinte csakis gróf Hoyos Miksáné adományai teszik lehetővé).

44 A vöröskereszt-egylet Szigetvár és vidéke egylete. Somogyi Hírlap, 1914. szeptember 18. 3. Feltétlenül ki kell hangsúlyozni Biedermann Ottóné nagylelküségét, akinek igen rövid időn belül ez már a második jelentős adománya; szeptember 10-én 3000 koronát adott az egyletnek. (Somogyi Hírlap, 1914. szeptember 10. 3.)
Határoznak, hogy a fiókegylet 1916. január 1-től napi 3 korona ápolási díjat kér az igazgatóságtól, és további 10000 koronát segélyként az eltelt időszak veszteségeinek pótlására, tekintettel arra, hogy az ingyenes ápolást a tervezettnél tovább tartották fenn. Meglehetősen bonyolult számítások alapján jutottak arra a következtetésre, hogy 5000 ápolási nap az a jogosnak tekinthető igény, ami napi 2 korona térítési díjjal kalkulálva teszi ki az igényelt segély összegét.

A következő, 1916. február 27-i közgyülésen már nem segély, hanem „egyösszegü költségtérítés” szerepel igényként, már csak 3594 ápolási napra számítva 7188 korona.

Általánosságban is érvényes, hogy az általunk vizsgált dokumentumok egyike sem tartalmazta a pénzügyi számvitel elvárható menetének megfelelő kimutatásokat, a bevételek-kiadások bizonylatait. A választmányi ülések, közgyülések jegyzőkönyvei is "nagyvonalúan” kezelik ezt a kérdéskört, feltehetően a fiókegyesületek megkérdőjelezhetetlen erkölcsi tekintélyü vezetőibe vetett feltétlen bizalom következményeként.

1915. évi bevétel összesen:

\section{2 korona 77 fillér.}

Részletezi:

Kiadás a kórházra: $\quad 13784$

Készpénz: $\quad 78 \quad 25$

Takarékpénztárban: 2000

A felelős előrelátásra utaló tervezéssel is csak egyetlen esetben találkoztunk, a szigetvári fiókegylet 1915-1916. évi titkári beszámolójában. Előterjesztés az 1916. évi költség-előirányzatokra (tervezet):

\begin{tabular}{lc}
\multicolumn{1}{c}{400 katona, } & 8000 ápolási nap \\
élelmezés (napi 3 korona) & 24000 korona \\
fütés, világítás & 1500 \\
gyógy- és kötszer & 2500 \\
felszereléskiegészítés, javítások & 1000 \\
felügyelő fizetése & 600 \\
szolga fizetése & 100 \\
írószer, nyomtatvány & 200 \\
tiszteletdíj (orvos és gondnok) & 2000 \\
összesen & 31900 korona
\end{tabular}

bevételmaradvány 1915-ből

2078 korona 25 fillér tagdíjak, egyesületi részesedés 250 igazgatósági gyógy- és ellátási költség térítménye (400 katonával, 8000 ápolási nappal, 3,50/nap) 28000 adományok 2000
összesen
32328 korona
25 fillér
bevételi többlet
428 korona 25 fillér

A már látható fenntartási nehézségek ellenére áprilisban aggodalmat vált ki a választmány tagjaiból az a rendelkezés, amellyel a belügyminiszter a közkórházakban lévő katonák felvételét megszünteti: elterjed a hír, 
hogy ez majd előbb-utóbb őket is érinteni fogja, tekintettel arra, hogy a náluk elhelyezett sebesültek szükséges mütéteit a közkórházban végzik el. $A$ föispánt felkérik a kórház érdekeinek védelmezésére. A belügyminiszter 5110/1916. VII. sz. rendeletével, majd ennek nyomán az alispán 10010/1916 sz. alatt megküldött értesítésével bizonyossá válik: maradhat a jelenlegi müködési gyakorlat. A döntésben Hoyosné közbenjárása sokat segített.

Ferenc Szalvátor főherceg, a Vöröskereszt fövédnöke a katonai egészségügy körül szerzett kiváló érdemeiért dr. Rusa Ernő szigetvári közjegyzőnek és Inkey József iharosberényi földbirtokosnak, a vöröskeresztegylet megbízottainak a vöröskereszt hadiékítményes másodosztályú díszjelvényét díjmentesen adományozta. ${ }^{45}$

A megyében 1916. március végéig meglehetősen sok, 140 személy kapott kitüntető elismerést. Ezek megoszlása:

$\begin{array}{lr}\text { Kaposvári járás } & 29 \\ \text { Barcsi járás } & 7 \\ \text { Nagyatádi } & 19 \\ \text { Marcali } & 7 \\ \text { Igali } & 2 \\ \text { Lengyeltóti } & 33 \\ \text { Szigetvári } & 29 \text { (köztük } 5 \text { apáca). }{ }^{46}\end{array}$

A szokásos Péter-Pál-napi gyűjtéshez csatlakozva részletes akciótervet dolgoznak ki a központtól kapott 43 gyűjtőív szétterítésére. Szigetváron sikeres az akció, a fiatalok 286 koronát gyűjtöttek, a felállított négy sátorban urnákban 311, a vöröskeresztes kitüzők eladásából 313, összesen 910 korona jött össze. Ugyanakkor a környékbeli községekhez kiküldött 43 íven 656 korona érkezett be. Jellemzi a helyzetet, hogy harminc ív „elveszett”, vagy talán nem is akartak gyűjteni. A kórházi felügyelő fizetésemelést kér, de már nincs rá fedezet. Hoyosné vállalja a 40-ről 60 koronára történő emelést, és azt is, hogy ezentúl maga fogja téríteni azt. Rontja a hangulatot, amikor kiderül, hogy a Magyar Szent Korona Országai Vörös-Kereszt Egyesületének rendkívüli közgyűlésére (Budapest, 1916. december 16.) a fiókegylet nem küldhet közvetlenül küldöttet, mert arra csak a megyei választmány jogosult.

Nincs leírva sehol, ám joggal feltételezhető, hogy a megbántottság motiválta azt az 1917. április 1-jén született „megoldást”, hogy kiválnak a megyei választmányból, és a Somogytarnóca és vidéke fiókegyesülettel közösen önálló „vidéki választmányt” hoznak létre, így biztosítva az érdekérvényesítést, a tekintély növekedését, benne a küldöttküldés lehetőségét. Tekintettel arra, hogy az országos egyleti megbízott Rusa Ernő - Szigetváron lakik, a „vidéki választmány” székhelye Szigetvár lesz. Mindkét fiókegylet választ-

45 Vörös-keresztes kitüntetések. Somogyvármegye, 1916. január 28. 4 .

46 Kitüntetett somogyi vöröskeresztesek. Somogyi Hírlap, 1916. április 1. 3. A lap megjegyzi, hogy néhányan kimaradtak a felsorolásból, a hibát később korrigálni kell. mánya elfogadja ezt a megoldást, így az áprilisi közgyülések mindkét helyen szentesítik azt.

Az 1916. év végi zárszámadás fő számai: bevétel: 27573 korona 38 fillér, kiadás 27013 korona 91 fillér, így a pénztári vagyon 559 korona 47 fillér. A takarékbetéti vagyon 1000 korona.

$A z$ 1917. április 22-én megtartott közgyülés jegyzőkönyvéből van tudomásunk róla, hogy a kórházban kilenc állandó önkéntes ápolónő 1916-ban 274 katonát 6409 , majd 1917. január 1 . és április 22. között 86 katonát 2055 napon át ápolt. Kötelességünknek érezzük név szerint is megemlékezni róluk: gróf Hoyos Miksáné, Herkovics Ilona, Karsai Józsefné, Kriszt Béláné, Kohn Riza, Major Elza, özv. Maurer Jánosné, Rostás Böske, Schlesinger Irén.

Az átlagos ápolási napok száma a teljes müködés során évente alig változott: 22 és 24 nap között volt. A hátországi viszonyok és a már bemutatott anyagi körülmények ismeretében nehezen indokolható (magyarázható) a választmány optimizmusa, amikor határozatot hoznak arról, hogy a kórházat bővíteni fogják, tekintettel az ápolási díjak emelkedésére, ${ }^{47}$ és mert „sok az ideutalt”.

$A z$ 1917. április 30-i választmányi ülés dokumentuma rövid és szűkszavú: „Határozat: $A$ választmány elhatározza, hogy a kórházat kibővíti, és ennek foganatosítására felkéri és felhatalmazza az orvost, gondnokot és titkárt." Ez az utolsó bejegyzés a jegyzőkönyvek sorában. Ebböl adódóan nincs lenyomata a viszonyulásnak, amelyet a Magyar Vörös-Kereszt Egylet korábbi országos vezetőségének leváltása és gróf Károlyi Mihálynénak a népkormány által történt kormánybiztossá való kinevezése váltott ki a fiókegylet tagjaiból. Az új kormánybiztos székfoglaló programbeszéde a Vöröskereszt egy teljes korszakának végét jelzi:

„Hódolva az érdemnek, mélyen meghajolva a vértanúságig menő ápolónői önfeláldozás előtt, nem hallgathatom el, hogy a vöröskereszt tevékenységét a viszonyok nehézségein túl szervezeti alaptévedések is oly mértékben akadályozták, hogy a vörös-kereszt iránt a közönség széles rétegeiben lehangoltság és elhidegülés támadt. A vörös-kereszt bizonyos életnyilvánulásait eredetben is értelmetlen, de az új időkből már éppenséggel kirívó kasztszerü elzárkózottság és szertartásos formalizmus jellemezte a reprezentatív teendők túlbecsülésével, aminek következményeképp olykor a legfontosabb helyekre is rendszeres tevékenységhez nem szokott $s$ a gyakorlati élettől idegen mükedvelőket állítottak, akik az intézményt nem tehették rokonszenvessé az arcvonal lerongyolt komoly mártírjai előtt. [...]

De a vörös-keresztre a háború sebein is túl hatalmas feladatok várakoznak. Az új Magyarország legnagyobb gondjainak egyike lesz a hygienikus demokrácia [sic!]. Nem fogjuk ennek feladatait orvossal győzni. Itt nyílhatik meg a vörös-kereszt aranykora. Küldje

47 Emelkednek az ápolási díjak. Somogyi Hírlap, 1916. augusztus. 3. Az ápolási díj legfeljebb 5 korona lehet naponta az élelmezés drágulása miatt. A nem kórházszerū ellátás tiszteknél az 5 koronát, legénység esetében a 3,50 koronát nem lépheti túl. 
szét szakképzett nénéinek egy részét Magyarország könnyázott falvaiba, legyenek a nénék ápolónői a faluk betegjeinek, járványok esetén irányítsák az izolálást és desinficiálást, figyelmeztessék a falu népét az egészséges lakás, táplálkozás, gyermeknevelés elönyeire. $E$ nénék [...] mielőtt a nép közé mennének, még kertészeti tanintézetet is végeznének: így ők a régi magyar nagyasszonyok jóságát, bölcsességét vihetnék széjjel megtört országunkba, s elhagyatott tanyákon is emberséges európai életigényeket támasztanának. [...]"48
A legközelebbi jegyzőkönyv szinte pontosan tíz évvel későbbi, az 1927. április 24-én történő újraalakulást dokumentálja. Megválasztott tisztikara a kényszerü szünet ellenére a folyamatosságot sugallja. Elnökök: Hoyos Miksa és dr. Rusa Ernőné, alelnökök: dr. Perczel Győző, özv. Hegyessy Jánosné, titkár: dr. Szily Ádám. ${ }^{49}$

\section{Irodalom}

BŐSzE S. 1986: Egyesületek Somogyban a dualizmus időszakában. - In: Kanyar J. (szerk): Somogy megye múltjából. Levéltári évkönyv, Kaposvár 17: 303-322.

BRÜLL M. 1984: A Magyar Vöröskereszt tevékenysége az első és a második világháború időszakában. - Magyar Vöröskereszt OVB, Budapest.

GÁsPÁR F. 2018: A Vörös Kereszt-Egylet tevékenysége és a kaposvári katonai kórházak. - In: Récsei B. (szerk.): Kaposvár az első világháború éveiben. Kaposvár [megjelenés alatt]
HORVÁTH J. 1943: Balatonlelle története. - Egyházmegyei Könyvnyomda, Veszprém.

SzUNDY K. 1916: Az első esztendő. Ismertetés és tanulmány a Magyar Vöröskereszt-Egylet háború alatti működéséröl. - Athenaeum Irodalmi és Nyomdai Részvénytársulat, Budapest.
48 Magyar Vörös-Kereszt. A Vörös-Kereszt Közlönye, 1918. december 10. 1. Elhangzott Budapesten, 1918. december hó 6-án, a Magyar Vöröskereszt országos választmányi ülésén. Ekkor változott meg a hivatalos névhasználat is.
49 MNL SML X. 204. Magyar Szentkorona Országainak VörösKereszt Egylete Szigetvári Fiókjának iratai. 
